\title{
THE RISK OF DROUGHT IN CROP PRODUCTION INSURANCE
}

\author{
Nebojša Žarkovićl, Jova Miloradićn ${ }^{2}$, Slobodan Samardžic ${ }^{3}$
}

\section{Summary}

The goal of this paper was to study the risk of drought as one of perils which can extremely harm the crop production, and also its coverage by insurance on the insurance market. In that purpose, first the forms of drought in agriculture and its effect on crops and yields were analysed. After that, this weather disaster was put in the spotlight from the insurance risk point of view. Special emphasis was placed on insurance against drought in our country. In implementing the process of risk management from drought, a common approach of insurance companies is that they simply do not offer this type of protection due to often huge potential damage. Such approach is common in insurance companies in high-developed west countries. It is obvious that there should involve government in the resolution of this issue, in order to protect food production as one of the basic preconditions for human survival.

Key words: insurance, the risk of drought, insurance of crop production, drought, crop production.

JEL: G22, Q19

\section{Introduction}

It is well known that natural disasters have been increasingly endangering man and his property in past decades. Different forms of these threats manifestations were encouraged by the fact that climatic changes have been continuing, along with the expected shortage of drinking water (World Economic Forum, 2016). From the food production point of view and future agricultural development, one of the growing threatening dangers is definitely drought.

In many areas, drought is common and it repeats without any noticeable principle and its

1 Nebojša Žarković Ph.D., Full Professor, John Naisbitt University Belgrade, Goce Delčeva Street no. 8a, 11070 Novi Beograd, Serbia, Phone: +381 11220 3000, E-mail: nzarkovic@,sbb.rs

2 Jova Miloradić Ph.D., Associate Professor, Educons University, Faculty of Business Economy, Vojvode Putnika Street no. 85-87, 21208 Sremska Kamenica, Serbia, Phone: +381214893 610, E-mail: jova.miloradic@gmail.com

3 Slobodan Samardžić Ph.D., Vice President, Chamber of Commerce and Industry of Serbia, Resavska Street no. 13-15, 11000Beograd, Serbia, Phone: +381 11 3300900, E-mail: slobodan.samardzic@pks.rs

EP 2016 (63) 4 (1297-1308) 
characteristics vary from region to region, depending on the perspective this phenomenon is observed from. For that reason, there is no clear definition of drought. It is about more present risk in past years and it represents the increasing threat for crop production.

This natural disaster occurs if there is a lack of moisture in the soil and it is one of the natural factors which can seriously jeopardize crop production (Žarković, 2013). In order to cause damage, a deviation in water supply has to reach a certain marginal value (Maliva, Missimer, 2012). The intensity of drought is mostly assessed according to the decrease of crop yields and fruits, provided that this did not affect other detrimental factors.

Drought has the character of systemic risk, because it can seize a large territory. Insurance against this risk of crop production is present in Austria, Italy, Spain, France, Luxemburg, Canada and USA. Insurance premiums are calculated according to an average yield of agricultural manufacturer, or an average yield in the region, if individual data are not available (Labudović Stanković, Todorović, 2011). Only with one insurer in Serbia drought was recognized as an insurable risk of crop production. The most significant consequence of drought is a fact that it jeopardizes the stable food production (Žarković, Toscano, 2015).

It is necessary to make a difference between drought and aridity. The aridity is a phenomenon when there is a shortage of precipitation compared to the needs. The lack of rainfall lasts very long, so these small values become normal rainfall for the region and are a feature of the climate of the area. Unlike aridity, drought is temporary reduction in water availability, which can cause damage in different fields of nature, economy and society (DMCSEE Project, 2012).

\section{Types of drought in agriculture}

Classification of agricultural drought is very complex, because it requires analysis of many agricultural impacts. Complexity of certain agricultural drought depends on many factors. The impact of drought on crop depends on the occurrence season, duration and intensity of drought.

Two types of drought differ in agro-meteorology: atmospheric and land drought (Petrevska, Toscano, Milošev, 2010).

Atmospheric drought - implies a longer period without precipitation followed by high temperature and low air humidity. In such conditions the above-ground parts of plants lose water intensively by transpiration. It is especially revealed on temperatures above $35^{\circ} \mathrm{C}$. Stomata remain opened, due to a stomatal complex paralysis, owing to which the plant loses moisture rapidly. Root system in such conditions is not capable to compensate fast the loss of water, the water balance of plant is disrupted and if these conditions last for a long time - the plant fades.

Land drought - is the most common in our country. They occur when easily accessible water spends from active rhisosphere. The plants consume harder affordable water and water from deeper soil layers at the expense of reductions in yield. The beginning of land drought is at the lower limit of optimal soil moisture for particular plant species and it lasts until the irreversible permanent withering. In that range of soil moisture plant suffer from water shortage, lose 
turgor, fade to a lesser or greater degree and provide low yields. The land drought is followed by air drought, which is common in summer season here.

We can differ winter, spring, summer and autumn droughts, depending on a season they appear (Sauchyn, Khandekar, Garnett, 2005).

Winter drought occurs in terms of reduced rainfall during winter, which results in the impossibility to create sufficient reserves of winter humidity necessary for the development of growing crops in spring. Winter season droughts have not been studied a lot before, though their consenquences can be very serious (Van Loon, Van Lanen, Hisdal, Machlica, 2010).

Spring drought occurs in terms of relatively low temperatures, dry air and often severe, cold and dry winds which drain land. This type of drought affects directly the slowdown of germ formation and germination of spring crops, tillering and enrooting becomes weak, and it leads to forming a smaller number of spikelet in a spike, while it reduces a number of young sprouts in tillering period regarding winter crops. Spring drought affects more harmful spring crops than winter crops, which already have well developed root system. However, if moisture reserves in the soil are already made during winter, this type of drought influences plants insignificantly.

Summer drought is characterized by low air humidity, high temperatures and high evaporation volume. It dries up the land, hastily reduces the growth of vegetative mass, causes the leaves drying up and reduces the photo-synthetic activity of plants. Harmful effects of the summer drought depend on a phase in plants evolution, the reserves of moisture in soil, as well as on the resistance of plants to drought. It always decreases, more or less, the yield of crops.

Autumn drought affects harmfully sowing, sprouting and germination of winter crops. As the germination in such conditions is usually late, plants enter the winter insufficiently developed, and their resistance toward low winter temperatures becomes reduced.

In that way, we can differ:

- Normal dry years - they occur once in five years or twenty times per a century $(20 \%$ of probability);

- Extremely dry years - they occur once in twenty years or five times per a century $(5 \%$ of probability);

- Normal series of dry years - series of three years which occurs once in five years or twenty time per a century ( $20 \%$ of probability);

- Extreme series of dry years - series of three years which occurs once in twenty years, or five times per a century ( $5 \%$ of probability).

The intensity of drought is evaluated mostly according to the decrease of yields, provided that other harmful factors had no effect on it. If the yield of a particular agricultural culture is reduced to $10 \%$, it is about weak drought, from $10 \%-30 \%$ - moderate drought, from $30 \%$ to $50 \%$ - severe drought, from 50\%-70\% - extreme drought, and over $70 \%$ - catastrophic drought (Petrevska, Toscano, Milošev, 2010). 


\section{Drought activity}

Drought is probably one of the most studied phenomenons in meteorology, i.e. agrometeorology. Drought, as well as floods, hunger etc. are common in societies at all levels of economic development. None of countries is protected from the influence of this natural disaster to the production and food/water reserves. For industrial countries, drought mostly represents an economic problem. Although the local conditions can be very unfavourable, the richer societies are able to overcome these difficulties. In the rest of the world, especially in poor countries, drought often can be a limit between life and death. Even the emergence of drought cannot be prevented; there are many ways to reduce the adverse effects of this disaster on humans and the economy (DMCSEE Project, 2012).

This disaster is one of the most harmful weather phenomenons. The seriousness and significance of this natural disaster depend on a level of water shortage, a size of the region under its influence, as well as duration and heat of a dry period. The phenomenon and intensity of drought on a smaller area also depend on the specific regional and local factors. This primarily relates to the annual amount of precipitations, distribution and intensity of rainfall during the year, evaporation intensity from soil and the air evaporation power, characteristics and conditions of soil and plant cover, groundwater level and series of other factors.

This natural disaster has a great influence to social-economic relations, life standard and the environment ecology. Direct consequences of drought are: reduced yield of grown crops, decreased productivity of forests, increased risk of fire, increased mortality of wild life. There are also indirect consequences. Reducing the productivity of agricultural production usually result in the reduction of income for agricultural manufacturers, the increase in prices of food, unemployment and migrations of population.

Many of numerous drought effects can be observed as economic, ecological or social (Table 1.).

However, not all consequences of drought are adverse. For example, agricultural manufacturers who are out of the area affected by drought, sell their products more expensive (Otorepec, 1980).

Drought doesn't make a problem only to manufacturers. Retail which provides a reproductive material and provides services to agricultural manufacturers must struggle with the reduction of business. This leads later to unemployment and the loss of tax revenues for the state. Source of tourism income is seriously endangered, because tourists do not want to travel to areas affected by drought. The shortage of agricultural products results in export of the essential commodities outside of the areas affected by drought. 
Table 1. Classification of drought effects

\begin{tabular}{|l|l|}
\hline & - Slowdown of economic development \\
& - Reduced food production \\
- Increased prices of food \\
- Increased import of food \\
- More intensive activity of harmful insects \\
- - Eore intensive activity of plant diseases carriers \\
- Reduced production of milk in livestock production \\
- Inaccessibility of water and food for livestock which leads to its high \\
mortality rate \\
- Disorder of social reproduction cycle \\
- Increased number of fires \\
- Increased losses in fishery \\
- Loss in agricultural manufacturers' incomes \\
- Growth of unemployment in agriculture \\
- Loss of income for tourism \\
- Reduction in electricity production \\
- Loss of navigability on rivers and canals \\
\hline Ecocial effects & - Increased damage of animal species \\
- Reduction of fish and game habitats \\
- Lack of food and drinking water \\
- Exacerbated air quality \\
- Loss of diversity of flora and fauna \\
- Increased stress in endangered species \\
- Damage of plant species \\
- Increased number and severity of fires \\
- Soil erosion \\
\hline - Shortage in food \\
- Loss of human lives due to food shortage \\
- Mental and physical stress \\
- Political conflicts \\
- Social unrest \\
- Inequality of distribution of aid after the drought \\
- Decreased life quality, which leads to the changes in a way of life \\
- Increase of poverty \\
- Migration of population \\
\hline
\end{tabular}

Source: Petrevska,Toscano, Milošev, 2010;

Note: The authors' own review

\section{The risk of drought in insurance}

The risk of drought is included by the insurance protection in the relatively small number of countries, and especially where the state is directly involved in subsidizing catastrophic damages and their insurance or reinsurance (Zarkovic, Toscano, Mrksic, Lisov, 2014). Likewise, it is wrong to think that the state support in the insurance of crop production is present only in high-developed countries. On the contrary, it is also expressed in numerous developing countries (Hussels, Sherman, Ward, Zurbruegg, 2007). 
There are many approaches to the insurance of crop production from adverse impact of drought in the world. They all can be classified in three groups:

- In the first group we can line up the approaches by which insurance companies try to define the aberrations of climatic factors (temperature, precipitations, air humidity etc. which have a direct impact to an income level) from multi-year average on specific areas;

- In the second group we line up the approaches by which insurance companies endeavour to define the aberrations of grown crop yields in the specific area from multi-year average;

- In the third group are the approaches by which insurance companies insure the loss of income of an insured person as a result of drought.

Insurers in all these cases determine independently up to what level are they ready to bear the risk from the decrease in crop production volume, whether by themselves, in joint insurance and reinsurance, or with the state support.

The experiences of countries are different, but the effects are mostly unsatisfying. There are many reasons for that. The biggest problem is that drought always seizes the whole regions, not small areas, and therefore insurance companies have no possibility to cover damage from their own resources. This is certain if we take into consideration the frequency of drought from year to year. Drought has almost become a certain risk - the only question is its intensity. At the same time, it is the main reason why many countries, i.e. their insurance companies give up from the insurance of this risk, or are at the very beginning of insurance. This also happens in high-developed countries like Germany, for example (Baltzer, 2016).

In such unfavourable conditions for the implementation of insurance protection against drought, the state has introduced a series of measures, alone or with the support of international organizations, in order to preserve crop production. Measures include recommendations for the cultivation of certain crops and hybrids or varieties in regions affected by drought, the required technology for growing crops, investment in irrigation systems and subsidies which amount depends on the volume of damage.

It is necessary to emphasize also the existence of the contemporary system of the weather index-based insurance. It is based on the specific meteorological parameters, and the damage compensates to agricultural manufacturers if a specific limit (precipitations or average temperature) was not attained or was exceeded (Marković, 2009). The damage will be paid, according to this approach, for example, if certain minimum temperature or precipitations (rainfalls) would be recorded in the specific time period, which is used to prove the realized risk from drought or excessive rainfalls. This is a new system of crop production insurance (weather indices), which has started to apply in nineties of $20^{\text {th }}$ century in the United States of America, and it has started to be used successfully in some developing countries in past years (Swiss Re, 2011).

The advantages of weather indices (derivates) in regard to a classical insurance system is that there is no moral hazard, adverse selection, as well as no assessment of damage, while they ensure also the significant isolation from the impact of political and economic risks. Weather 
derivates have the ability to provide protection regarding less extreme incidents, because it starts from the fact that a deviation of only a few millimetres of rain, or a few degrees of temperature, can significantly jeopardize farmers' incomes. Imperfections of the weather derivates, inter alia, lies in a fact that they do not cover catastrophic incidents, followed by high risks and low probability of their occurrence (Marković, 2016).

\section{Insurance against drought in the insurance of crop production in Serbia}

In past decades, we have more often met the negative effects of drought on crop production (Radičević, 2016). Only one insurance company on domestic market of agricultural insurance offers the insurance against risk of drought. This insurance company has started to insure crops against risk of drought in 2010, in order to meet the requirements of agricultural entities caused by climatic changes and the global warming phenomenon. It is interesting to say that agricultural manufacturers in surrounding countries consider as the real agricultural insurance only the one which also covers the risk of drought (Radović, 2016).

The object insured, according to the conditions of this insurance company cannot be fruits, only crops (Posebni uslovi za osiguranje useva i plodova od rizika suše):

- Mercantile and seed maize;

- Mercantile and seed soy;

- Mercantile sugar beet.

The insured risk of drought, under which is meant the reduction of authoritative precipitation in regard to authoritative multi-year amount of precipitation.

There considers that insured case origins by the realisation of insured risk of drought and by meeting both of these conditions:

- That the recorded authoritative amount of precipitation is lower than the authorative multi-year amount of precipitation for more than $30 \%$ in the specific risk zone;

- That a fixed yield per area unit is reduced for over than $10 \%$ owing to the reduction of authoritative amount of precipitation in regard to the authoritative multi-year amount of precipitation in that risk zone.

Duration of insurance - the insurance against this risk can be effected:

- For mercantile sugar beet until April $30^{\text {th }}$ of current year;

- For mercantile and seed maize until May $10^{\text {th }}$ of current year;

- For mercantile and seed soy until May $31^{\text {st }}$ of current year.

In insurance clauses is quoted that insurer can postpone deadlines for insurance of mentioned crops, depending on optimal sowing deadlines postponement due to climatic characteristics. Obligation of insurer starts after the termination of $24^{\text {th }}$ hour of the day delineated at insurancepolicy as the beginning of insurance, if an insurance premium is paid in time, and it ends by the termination of $24^{\text {th }}$ hour of the day delineated on the insurance policy as expiration of insurance. 
The basis for the calculation of the premium per unit area is a contracted value of insured crop per area unit, which is calculated as a product of contracted yield per mass unit at the time of conclusion of a contract and for each insured object individually.

Other regulations in special insurance clauses from the risk of drought are similar as other special clauses in the insurance of crops and yields of insurance companies on domestic market.

This insurer considers drought as the reduction of precipitation amount in regard to the multi-year average of precipitation. As we can see, depending on the reduced amount of precipitation, which must be higher than $30 \%$, there recognizes the reduction of yields for $10 \%-30 \%$. We consider this as not right insurance against drought if we know that more than 30 factors affect drought, including precipitation as the most important, but not the only one (Žarković, 2015).

Insurance against the risk of drought, despite of the existence of demand, is not offered by insurance companies which do business on domestic market. The reason lies mostly in a fact that insurers cannot find it profitable to offer the insurance against drought, in regard that significant financial assets must be available for compensation. Therefore insurers usually think that the compensation for damage should be divided between them and the state. However, in our country the increasing attention is paid on the insurance protection from drought, which can be assessed as favourable (Čolović, Petrović Mrvić, 2014).

\section{Managing the risk of drought from insurance companies point of view}

Taking into consideration that insurance companies, in historical sense, were focused on the adverse incidents of local intensity and for which there was relevant the historical experience, as well as the fact of climate and its global changes complexity, the adequate assessment of probability of the occurrence and intensity of adverse consequences of extreme natural catastrophic disasters have represented a significant challenge.

Responsibility of insurance companies is double, because they should be prepared for the negative effects which climatic changes can have on their business and their clients, and on the other hand, they can substantially contribute to risk minimization by providing the adequate solutions for covering those risks within the program of risk management.

All definitions of drought are quite broad and generalized. They mainly start from shortage of water and needlessly exaggerate the necessary level of resources for elimination or mitigation of drought negative effects. Besides, such generalized and unsteady definitions of drought are often the result of indecision to declare drought as natural disaster (Žarković, 2013).

Absence of a universally accepted definition of drought (more than 100 different indices of drought are used in the world today) makes certain confusion in terms of determining the beginning and the end of drought and the level of its intensity. There should strive to define drought more completely according to water and heat balance on Earth's surface, i.e. to make scientific-based evaluation of the volume and intensity of drought. The goal is to make a difference between droughts regarding their duration and intensity, among customary droughts which occur regularly on some territory and make that territory characteristic, unlike 
droughts which rarely occur, but with catastrophic consequences. The main goal should be to highlight the intensive and long-lasting droughts which are outside the scope of normal risk management, by which the state intervention would be justified.

Quantification of drought refers to precipitation and its influence. In this context, it is necessary to categorize droughts depending on their intensity and frequency, not only by their nature.

There are several levels of drought, which insurers must have in mind when they manage risk rationally (Marković, Jovanović, 2008):

- Mild drought which occurs ones in three to five years and covered by the measures which manufacturers implement by themselves;

- Temperate drought which, in its scope, requires the intervention;

- Severe drought which seizes whole regions and owing to which the financial and material reserves of a country mobilize; it is even counted on foreign support in case of insufficient reserves;

- Very rare extreme drought which is often declared as catastrophic due to accompanying consequences, and requires justified participation and support of international humanitarian organizations.

It is inevitable to make regionalization after the done classification, i.e. to divide the territory of a country into regions, depending on the intensity of droughts over a long period of time. It should be borne in mind what is normal climate and what drought means.

Insurance companies should calculate the highest possible damage and the compensation amount for several drought intensities, and then follows the calculation of insurance premiums against drought. The level of premium as the price of insurance should be adjusted both to the degree of danger and the economic possibilities of insureds.

It is necessary to classify the regions covered by drought according to its intensity for the specific crops. Once it is determined, an insurer is obliged to pay off damage to an insured if the agreed threshold of drought is achieved. In such conditions, regardless to the amount of damage, i.e. decreased yield in case of drought, the insured acquires the right to compensate. If the insured has grown crops resistant to drought with shorter vegetation period and could remain undamaged or minimally damaged, he/she still acquires the right to compensate damage. On the other hand, if the insured takes risk by growing crops with long vegetation period, hoping to a favourable year in order to realize higher yields, damages caused by drought will be higher than the compensation for damage.

The benefit of this insurance is that a farmer can cultivate also riskier crops which provide high average gains, and is protected from the effects of the occasional bad season. With this insurance, a manufacturer faces uncertainty in the amount of damage in comparison with the amount of compensation for damage from year to year, but a favourable circumstance is that the risk is balanced and the insurance protects agricultural manufacturers from extreme losses. We consider that this form of insurance would be economically justified and in longterm interest of the entire society. 


\section{Conclusion}

Insurance of crop production provides the immeasurable contribution to the protection of food production as an important precondition for mankind survival. One of the risks comprised by this form of insurance is also the risk of drought. Due to climatic changes, its influence on the production of crops and yields increases as time passes.

In this paper was given the interpretation of drought which jeopardizes agriculture and its divisions from different aspects in theory and in practice. Likewise, there the effects of drought were studied. It has the negative effects on human environment. These effects can be economic, social and ecological.

It is interesting that, even in high-developed countries, the insurance companies offer unwillingly the inclusion of drought in insurance of crop production due to frequent catastrophic consequences it causes. The same is in Serbia, where only one insurance company covers this form of insurance, but in fact drought is related only to the amount of precipitation in insurance clauses, and not to other points such as air temperature, number of sunny days, wind strength, etc.

We can evaluate as positive that insurance companies however slowly start to pay increasing attention to protection against drought, offering also new possibilities like the use of weather indices and contemporary achievements in risk management. Only by this overall access and with the greater inclusion of state, there could provide the appropriate insurance protection of crop production, which will comprise also the risk of drought.

\section{Literature}

1. Baltzer, C. (2016): Steigende Dürre-und Hagelschäden machen bestimmte Kulturpflanzen unversicherbar, Value, no. 1, pp. 42-43.

2. Čolović, V., Petrović Mrvić, N. (2014): Osiguranje useva - rizici i modeli osiguranja, Ekonomika poljoprivrede, vol. 61, no. 3,pp. 561-573, Institut za ekonomiku poljoprivrede, Beograd, Serbia.

3. DMCSEE Project, (available at: http://www.dmcsee.eu).

4. Hussels, S., Sherman, C., Ward, D., Zurbruegg, R. (2007): South and East Asian Insurance Market Growth and Development, in Handbook of International Insurance, ch. no. 17, pp. 849-876, Springer, New York, USA.

5. Labudović Stanković, J., Todorović, N. (2011): Osiguranje biljne proizvodnje u EU i Srbiji, Ekonomika poljoprivrede, vol. 58, no. 4, pp. 723-734, Institut za ekonomiku poljoprivrede, Beograd, Serbia.

6. Maliva, R.G., Missimer, Th.M. (2012): Air Lands Water Evaluation and Management, Springer, New York, USA.

7. Marković, T. (2016): Ekonomski instrumenti za transfer rizika - vremenski derivati $i$ upravljanje rizikom u poljoprivredi, Poljoprivrednikov poljoprivredni kalendar 2016, pp. 75-77, Dnevnik-Poljoprivrednik, Novi Sad, Serbia. 
8. Marković, T. (2009): Osiguranje useva i plodova као instrument za upravljanje rizikom u poljoprivredi, Letopis naučnih radova, vol. 33, no. 1, pp. 28-35, Poljoprivredni fakultet, Novi Sad, Serbia.

9. Marković,T., Jovanović, M. (2008): Postojeći sistemi osiguranja useva i plodova као instrument za upravljanje rizikom u poljoprivredi, Agroekonomika, no. 39-40, pp. 110116, Poljoprivredni fakultet, Novi Sad, Serbia.

10. Otorepec, S. (1980): Agrometeorologija, Nolit, Beograd, Serbia.

11. Petrevska, M., Toscano, B., Milošev, D. (2010): Osiguranje biljne proizvodnje, Beograd, Serbia.

12. Radičević, Z. (2016): Pojava suše u Srbiji u 21. veku, Poljoprivrednikov poljoprivredni kalendar 2016, pp. 78-80, Dnevnik-Poljoprivrednik, Novi Sad, Serbia.

13. Posebni uslovi za osiguranje useva i plodova od rizika suše, Generali osiguranje Srbija, 2016, Beograd, Serbia, (available at: http:/www.google.rs/url?url=http://www.generali. rs/Data/Files/posebni uslovi za osiguranje useva i plodova_20160302.pdf).

14. Radović, G. (2016): Poljoprivredno osiguranje kao moguća vrsta obaveznog osiguranja u Republici Srbiji, doktorska disertacija, Fakultet za poslovne studije, Beograd, Univerzitet „Džon Nezbit”, Beograd, Serbia.

15. Sauchyn, D., Khandekar, M., Garnett, E.R. (2005): The Science, Impacts and Monitoring of Drought in Western Canada, Canadian Plains Research Center, Regina, Canada.

16. Swiss $\operatorname{Re}$ (2011): Insurance in emerging markets: growth drivers and profitability, Sigma, no. 5, Swiss Re, Zurich, Switzerland, (available at: http:/www.swissre.com/sigma/).

17. Van Loon,A., Van Lanen, H., Hisdal, H., Machlica, A. (2010): Understanding hydrological winter drought in Europe, IAHS Press, Wallingford, UK, (available at: https://www. researchgate.net/publication/232167668_Understanding_hydrological_winter_drought in_Europe).

18. World Economic Forum (2016): The Global Risks Report, Part 1 - Global Risks 2016, (available at: http://reports.weforum.org/global-risks-2016/part-1-title-tba/).

19.Zarkovic, N., Toscano, B., Mrksic D., Lisov, M. (2014): Key Features of Crop Insurance in Serbia, Bulgarian Journal of Agricultural Science, vol. 20, no. 1, pp. 23-33, (available at: http://www.agrojournal.org/20/01-06.htm).

20.Žarković, N. (2015):Stanje u osiguranju biljne proizvodnje u Srbiji - Još uvek bez unapređenja ponude, Svet osiguranja, No. 4, pp. 31, Tectus, Beograd, Serbia.

21.Žarković, N. (2013): Pojmovnik osiguranja, Skonto, Novi Sad, Serbia.

22.Žarković, N., Toscano, B. (2015): Drought Catastrophe Risk and its Impact on Sustainable Agricultural Development, in Catastrophic Risks and Sustainable Development, ch. no. 17, pp. 285-303, University of Belgrade, Faculty of Economics Publishing Centre, Belgrade, Serbia. 


\title{
OPASNOST OD SUŠE U OSIGURANJU BILJNE PROIZVODNJE
}

\author{
Nebojša Žarković4, Jova Miloradićc ${ }^{5}$ Slobodan Samarď̌ic ${ }^{6}$
}

\section{Rezime}

Cilj ovog rada je bio da se istraži rizik od suše kao jedna od opasnosti koje mogu naneti izuzetno ozbiljne štete biljnoj proizvodnji, te njegova obuhvaćenost osiguravajućom zaštitom na tržištu osiguranja. U tu svrhu najpre su analizirani vidovi suše u poljoprivredi i njeno dejstvo na useve i plodove. Potom je ova vremenska nepogoda stavljena u žižu istraživanja sa stanovišta samog rizika osiguranja. Poseban naglasak dat je na osiguranje od suše u našoj zemlji. Prilikom sprovođenja procesa upravljanja rizikom od suše čest pristup kod društava za osiguranje jeste da jednostavno ne nude ovaj vid zaštite zbog neretko ogromnih mogućih šteta. Ovakav pristup je čest $i$ kod osiguravajućih društava u razvijenim zapadnim zemljama. Očigledno je da u rešavanje ovog otvorenog pitanja treba uključiti i državu kako bi se zaštitila proizvodnja hrane kao jedan od osnovnih preduslova za čovekov opstanak.

Ključne reči: osiguranje, opasnost od suše, osiguranje biljne proizvodnje, suša, biljna proizvodnja.

4 Prof. dr Nebojša Žarković, redovni profesor, Univerzitet „DžonNezbit”, Ulica Goce Delčeva 8a, 11070 Novi Beograd, Srbija, Telefon: +381 11220 3000, E-mail: nzarkovic@,sbb.rs

5 Prof. dr Jova Miloradić, vanredni profesor, Univerzitet „Edukons”, Fakultet poslovne ekonomije, Ulica Vojvode Putnika 85-87, 21208 Sremska Kamenica, Srbija, Telefon: +381 214893 610, E-mail: jova.miloradic@gmail.com

6 Dr Slobodan Samardžić, potpredsednik, Privredna komora Srbije, Ulica Resavska 13-15, 11000 Beograd, Srbija, Telefon: +381 11 3300900, E-mail: slobodan.samardzic@pks.rs 